\title{
11
}

\section{Retirement income strategies for an ageing population}

\author{
Hazel Bateman
}

The aim of this chapter is to assess the ability of Australia's system of retirement income provision to withstand the implications of population ageing. It is argued that Australia's retirement income arrangements are better placed that those in most other developed countries due to both a slightly slower pace of population ageing and its unique approach to policy design for retirement income provision. However, an implication of the increased fiscal pressures associated with population ageing will be a greater role for the private sector in funding of retirement incomes, health and aged care. The greatest challenge will be to work out how both the government and private sector can best assist individuals and households to deal with increasingly complex financial decisions, particularly as they relate to saving for and spending down in retirement.

The chapter proceeds as follows. In the next section, Australia's current retirement income arrangements and relevant demographic trends are summarised. This is followed by an assessment of the impact of the demographic trends on the ability of the retirement income arrangements to deliver adequate and sustainable retirement incomes. We then evaluate the effectiveness of the current policy framework 
to assist older Australians in their interactions with the increasingly complex decision environment, and a final section concludes with a menu of possible policy options.

\section{Policy and demographic background}

\section{Retirement incomes}

Over the past 30 years, Australia's system of retirement income provision has evolved into a multi-pillar arrangement comprising a means-tested Age Pension financed from general tax revenues, a mandatory employer-financed defined contribution (DC) scheme known as the Superannuation Guarantee, and tax incentives to encourage voluntary superannuation contributions and other private savings. The 'first pillar' Age Pension is paid at a rate of around 28 per cent of male average full-time earnings for singles and 41 per cent for couples and is currently indexed to keep up with wages in the rest of the economy. Net replacement rates are higher because no tax is paid on Age Pension payments. The Age Pension is available from age 65 (increasing to 67 between 2017 and 2023) ${ }^{1}$ and is paid subject to income and assets (means) tests, which have the effect of excluding the top 30 per cent of the wealth distribution from the Age Pension. Around 60 per cent of retirees (of eligible age) receive the full rate, while the remainder receive a part pension (Department of Social Services 2014). The means tests are comprehensively defined, although the assets test excludes owner-occupier housing.

The 'second pillar' Superannuation Guarantee commenced in 1992 as a derivation of productivity award superannuation introduced in the 1986 National Wage Case. The Superannuation Guarantee requires all employers to make contributions on behalf of their employees into a superannuation fund. The mandatory contribution gradually increased from 4 per cent to 9 per cent between 1992 and 2002 and, following a decision to increase it to 12 per cent, currently stands at 9.5 per cent. $^{2}$

1 In its 2014-15 Budget, the government announced plans to further increase the Age Pension eligibility age to 70 by 2035 .

2 The mandatory employer contribution is scheduled to rise to 12 per cent by 2026 . 
These first two pillars are supplemented by 'third pillar' voluntary longterm savings that include voluntary superannuation contributions (currently made by around one-third of super fund membersABS 2009) and property, shares, managed funds and home ownership.

Benefits from superannuation savings can be taken at the statutory preservation age, currently age 55, but increasing to age 60 by 2024 . Individuals are free to choose how they take their retirement benefits from a menu that includes lump sums, account-based pensions and life and term annuities. When the multi-pillar design was first adopted in 1992, differential tax and means tests encouraged purchase of lifetime annuities. However, due to low take-up of these products and strong lobbying from the financial services sector, these targeted provisions were diluted over the following 15 years. The Simpler Super reforms of 2007 (Australian Government 2006) removed all taxes on superannuation benefits taken from age 60 and eliminated the differential treatment and are considered largely responsible for the (temporary) disappearance of the annuity market in the late 2000s (Bateman and Piggott 2011). Today, almost all retirees take their superannuation benefits in a non-annuitised form (lump sums or account-based pensions), although, as discussed later, there has been a recent sharp increase in the number of life annuity policies sold, albeit from a very low base of less than 30 annually in 2009 to over 4,000 in 2014 (Plan for Life 2015).

Around 95 per cent of employees are covered by the mandatory superannuation arrangements, and compliance is high, with only those who are too young (i.e. under 18) or too poor (i.e. earning less than $\$ 450$ per month) excluded from the arrangements.

For many retirees, mandatory and voluntary superannuation is supplemented by a full or part Age Pension. Including Age Pension eligibility, the Australian Treasury estimates that a fully mature Superannuation Guarantee can be expected to deliver a net replacement rate of around 90 per cent (78 per cent) for a worker on median (average) earnings (Gallagher 2012). 


\section{Australia's ageing population}

The most recent statement of Australia's demographic position is set out in the 2015 Intergenerational Report (Commonwealth of Australia 2015). According to this report, Australians will live longer than projected previously and will continue to have one of the longest life expectancies in the world. Currently, Australia ranks equal first along with Iceland in terms of male life expectancy and fifth for female life expectancy after Japan, Spain, France and Italy. Male life expectancy at birth is projected to increase from 91.5 years today to 95.1 years in 2055, and female life expectancy from 93.6 years to 96.6 years. Despite later retirement ages, it is expected that there will be an increase in the number of years spent in retirement, and therefore an increase in the funds required to sustain living standards throughout retirement.

As a consequence of both increased longevity, and a stabilisation of the fall in the fertility rate, the proportion of the population aged 65 and over is expected to increase from 15 per cent today to 22.6 per cent by 2055 , and the absolute number of people aged 65 and over will more than double, from 3.6 million today to around 8.9 million by 2055. The obvious implication of these trends is that there will be fewer people of working age to support those in retirement. More specifically, the number of Australians of working age (15-65) available to support each Australian over age 65 will fall from around 4.5 today (which itself has fallen from 7.3 in 1975) to around 2.7 by 2055 . While these trends appear severe, they must be considered in the international context where, due to a slightly higher birth-rate and higher immigration, Australia is ageing at a much slower rate than many other developed countries (OECD 2014a).

On the basis of these demographic projections, the 2015 Intergenerational Report reveals an increasing gap between Commonwealth government expenditure and tax revenue under an unchanged tax system (that is, assuming tax revenue remains at 23.9 per cent of GDP over the projection period). ${ }^{3}$ In particular, with no change to current policy settings, Commonwealth government spending on health is projected to increase from 4.5 per cent of GDP today to 5.5 per cent in 2055, on aged care from 0.9 per cent of GDP to

323.9 per cent is the average of tax revenue to GDP over $2000-08$. 
1.7 per cent, and on the Age Pension from 2.9 per cent of GDP today to 3.6 per cent in $2055 .{ }^{4}$ These figures suggest that there will be continued pressure on successive governments to reduce expenditure on these aged-related budget items.

In sum, the most likely impact of population ageing on retirement incomes and retirees will be an increase in the role of private provision in the funding of retirement incomes, health and aged care for possibly longer retirements. Next we explore the extent to which Australia's retirement income arrangements are designed to withstand this demographic pressure.

\section{What does population ageing mean for retirement income policy? ${ }^{5}$}

The design of Australia's multi-pillar approach to retirement income provision has long been considered international best practice (World Bank 1994; OECD 2014b) largely due to the risk diversification provided through a combination of public and private provision (the Age Pension and superannuation), pay-as-you-go (PAYG) and pre-funding (the Age Pension and DC superannuation) and compulsion and individual choice (the mandatory Superannuation Guarantee and tax concessions for voluntary superannuation). Australia is consistently ranked in the top three pensions systems worldwide under the Melbourne Mercer Global Pension Index where scores reward adequacy, sustainability and integrity (Mercer 2014). However, a more careful assessment raises concerns about gaps in overall policy design (particularly as they relate to superannuation taxation and decumulation), and the increasing emphasis on individual responsibility and decision-making, the latter of which is an inevitable consequence of its DC design.

4 The 2015 Intergenerational Statement reports that the future cost of the Age Pension would fall to 2.7 per cent of GDP by 2055 had a 2014 Budget proposal to reduce the level of indexation been implemented. The long-term budgetary implications of the subsequent decision (announced in the 2015-16 Budget) to instead alter the assets test taper has not been officially reported, although the impact will be a reduction in future cost of the Age Pension to below 3.6 per cent GDP, the no policy change counterfactual.

5 Parts of this section are drawn from Bateman et al. (2016a). 
Retirement income systems are typically assessed from the perspective of their impact on both the broader economy and its citizens as they enter and move through retirement. The individual criteria focus on the ability of the retirement income arrangements to provide insurance against the key economic and financial risks an individual may face over this period (specifically replacement risk, investment risk, longevity risk, inflation risk and contingency risk), ${ }^{6}$ while the economy-wide criteria relate to economic efficiency and equity, the standard measures for evaluating public policy, as well as long-term sustainability and administrative efficacy.

\section{Economy-wide assessment}

Turning first to sustainability: on the face of it, the projected future population trends reported in the 2015 Intergenerational Report, which feed into a projected 50 per cent increase in the aged dependency ratio over the next 40 years, could signal severe problems for the future funding of retirement incomes. However, in the case of Australia, the policy framework of a means-tested Age Pension combined with mandatory superannuation participation and contributions (as required under the Superannuation Guarantee), and a relatively slower ageing of the population than much of the developed world, results in some of the lowest current and forecast levels of spending on public pensions in the OECD. The projection that spending on age-related pensions will increase from 2.9 per cent of GDP in 2015 to 3.6 per cent of GDP by 2055 (Commonwealth of Australia 2015) ${ }^{7}$ is far more sustainable than corresponding projections for other OECD countries (OECD 2014b). By comparison, over the next 40 years, public pension expenditure is projected to increase to 25 per cent of GDP in Greece, 15 per cent of GDP in Italy, Germany and Norway and 8-10 per cent in the Netherlands and Denmark (or 2.5 times the spending in Australia), who, with Australia, make up the top three in the global pension index rankings (Mercer 2014).

6 The individual criteria are drawn from Bodie (1990) as extended by Bateman and Piggott (1997).

7 In the absence of policy change. This does not include spending on public sector pensions, which is projected to fall from 0.4 per cent to 0.2 per cent of GDP over this period. 
Australia's retirement income arrangements also fair well in terms of overall economic efficiency and equity. Economic efficiency is enhanced where policy settings facilitate incentives to work and save, and DC systems, such as Australia's Superannuation Guarantee and voluntary superannuation arrangements, implicitly include incentives to work and save because later retirement translates into more contributions over more years and fewer years over which to spread the resulting income, resulting in higher replacement rates. This compares with publicly provided defined benefit (DB) PAYG second pillars operating in many OECD countries, which are generally funded from payroll taxes, and where inbuilt benefit formulas make it costly to deviate from a set retirement age. While the Age Pension means tests will erode the advantages in the Australian arrangements for some levels of earnings and superannuation assets and income, recent changes have been made to the Age Pension means tests to lower the penalty for income from employment. And, although the availability of superannuation benefits up to 10 years prior to the Age Pension eligibility age may encourage early retirement and dissaving, analysis of drawdown behaviour suggests that Australian retirees are not in a hurry to dissipate their superannuation accounts (Wu et al. 2015).

It is widely agreed that the pre-funding associated with Australia's DC superannuation has enhanced private saving. Superannuation assets now total more than $\$ 2$ trillion, well over 100 per cent of GDP and one of the largest pools of retirement assets in the world (APRA 2015). And, despite initial concerns about saving substitution, most of this represents 'new' saving (Gruen and Soding 2011). Furthermore, being pre-funded, Australia's superannuation arrangements score well on intergenerational equity, with each generation funding its own retirement.

However, concerns about intragenerational equity remain, largely due to the tax regime for superannuation that has resulted in tax concessions skewed towards the higher end of the income/wealth distribution (Henry 2010; Department of Treasury 2012). Super tax has been on and off the reform agenda since the early 1980s, and, in spite of constant tinkering, successive governments have failed to develop an effective tax regime. Australia's approach differs from international practice and departs significantly from the standard approaches 
that are more consistent with an economically efficient system. ${ }^{8}$ In particular, Australia operates a TTE system, where contributions to super funds are taxed (T), super fund earnings are taxed (T) and benefit payments are tax-free (E). Most of the rest of the world operates an EET system, where contributions are free of tax (E), fund income accumulates tax-free (E) but benefits are taxed (T) generally under the personal marginal tax schedule. Since under Australia's TTE regime, employer contributions and super fund earnings are taxed at a flat rate, they are also separated from income tax and its progressivity. Separating superannuation taxes from personal income tax has facilitated tinkering because changes are not obvious to fund members. Moreover, the regressive nature of flat rate taxes has resulted in regular, but piecemeal (and often politically motivated), policy initiatives designed to improve intragenerational equity - such as the excess contributions tax, low-income superannuation contributions, government co-contributions and the extra contributions tax now applying to high-income earners (which income plus employer superannuation contributions in excess of $\$ 300,000 \mathrm{pa}$ ).

In its final report, the Henry Tax Review recommended that the taxation of superannuation contributions be linked to the progressive personal rate schedule, and that the tax on superannuation fund earnings be reduced to help the power of compound interest generate more accumulations and reduce price distortion between assets and over time (Henry 2010). Unfortunately, governments from both major political parties have ignored these recommendations and instead continued to tinker with the tax treatment of contributions at the top and bottom end of the income distribution.

Finally, while international comparisons of mature-age poverty rates appear to paint a negative picture of Australia's retirement income system, with recent OECD data indicating that older Australians have some of the lowest incomes and highest poverty rates in the OECD (OECD 2013), it is essential to point out that this particular comparison is misleading in the case of Australia. First, as the OECD acknowledges, the Australian figures may be subject to upwards bias, since a large proportion of retirement benefits are taken as lump sums, which are excluded in the OECD analysis. Second, closer analysis

$8 \quad$ See Bateman et al. (2001). 
of the data reveals that the average difference between the poverty line and the incomes of poor households is one of the lowest among developed countries, and that many Australian retirees have incomes just below the poverty line. Finally, unlike most OECD countries, older Australians have very high levels of owner-occupied housing, and public spending on services for the aged is one of the highest in the OECD. Once housing costs are taken into account, old-age poverty rates are around 15 per cent, which is low compared to many other countries (ACOSS 2014).

\section{Individual assessment}

Coverage against the economic and financial risks individuals face as they enter and move through retirement is assessed by the ability of the retirement income system to insure against the risk of running out of retirement savings due to one or a combination of investment risk (the risk of unevenness in income due to volatility of investment returns), longevity risk (the risk of outliving savings), and inflation risk (the risk of erosion of purchasing power), as well as the ability to access funds to address uninsurable risks (often known as contingency risk). Here, Australia's retirement income system performs poorly.

The superannuation system, in common with DC schemes generally, does not guarantee a final benefit (let alone one that is at least CPI-indexed with payment guaranteed irrespective of age and market conditions). While the Superannuation Guarantee mandates participation in the superannuation system and a minimum contribution rate into a superannuation account, there is no requirement that the retirement accumulation be taken in a form that would provide cover against the key retirement risks.

Current take-up of retirement benefits is split evenly between lump sums and income streams, with very little interest in annuitised benefits. Recent trends are illustrated in Figures 1 and 2 below, which show a clear switch from lump sums to income streams since the mid1990s (Figure 1) and a sharp increase in the take-up of account-based pensions (Figure 2). It is important to point out here that despite being called a 'pension', an account-based pension is in fact a phased (or programmed) withdrawal from a superannuation account, which provides flexibility of payment (subject to the minimum drawdown requirements for tax purposes), but no insurance against investment, 
POPULATION AGEING AND AUSTRALIA'S FUTURE

inflation or longevity risk. The least popular benefits (term and lifetime annuities) do provide protection against market risk (both) and longevity risk (for the lifetime version) and can be purchased with CPI indexation.

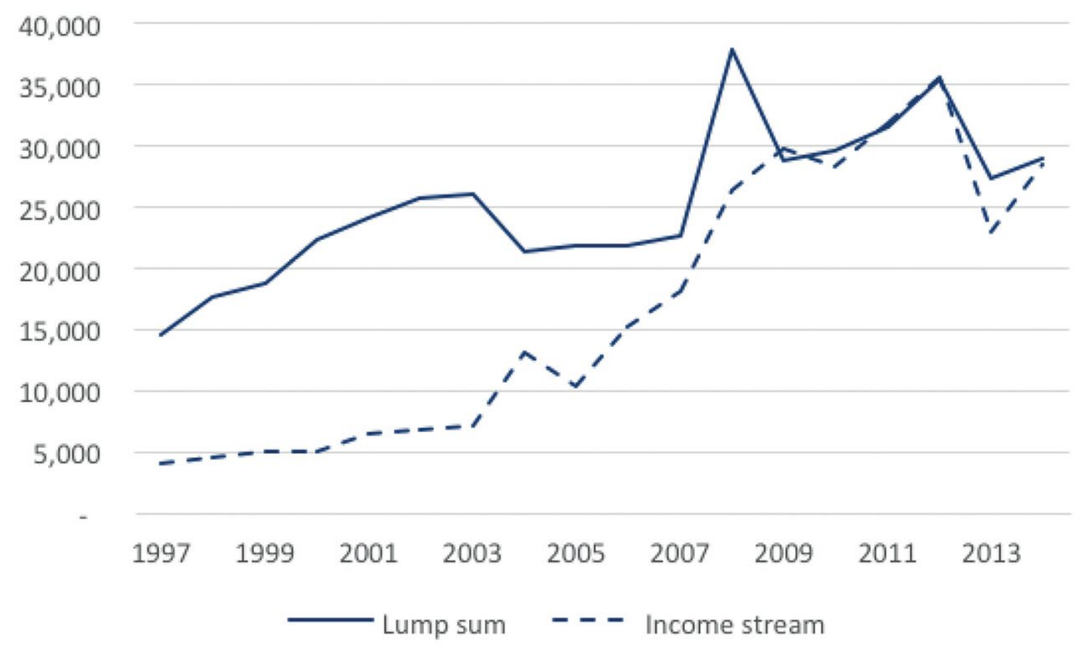

Figure 1: Superannuation benefit payouts, $\$$ '000 pa

Source: APRA $(2014,2015)$.

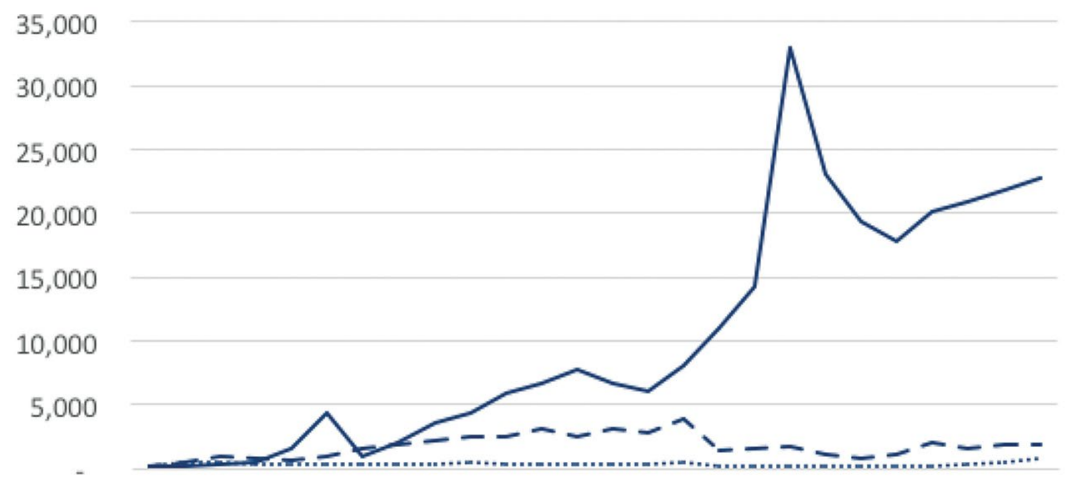

1989199119931995199719992001200320052007200920112013

- - - Term annuity

Lifetime annuity

Account-based pension

Figure 2: Take-up of retirement income streams, \$'000 pa

Source: Plan for Life (2015). 
The lack of interest in lifetime annuities is likely due to a complex range of factors relating to the demand for annuities, the supplyside of the annuity market and the regulatory and policy framework. The demand-side is influenced by standard rational factors such as adverse selection, incomplete markets, demand for liquidity, desire to leave a bequest, pre-existing annuitisation (for example, from the Age Pension and/or DB pensions) and intra-family transfers (Brown 2008) as well as behavioural factors due to framing (Brown et al. 2008; Agnew et al. 2008), defaults (Benartzi et al. 2012), loss aversion, myopia and complexity (Brown 2008). The supply-side in Australia has all but disappeared, with only one provider remaining (down from between 12 and 15 in the late 1990s) and is characterised by a short menu of products, and an overall lack of interest by the financial planning community, which increasingly influence decisions at retirement. ${ }^{9}$ Finally, the policy framework is also partly to blame with regulatory restrictions on the features of retirement benefit products that receive concessional treatment under the Age Pension means tests and tax rules. Current regulations exclude deferred and variable annuities from the menu of possible products and is partly to blame for the diminished supply-side, as highlighted in the Henry Tax Review Final Report (Henry 2010)..$^{10}$

That said, interest in lifetime annuities, which fell to a record low of 29 new policies in 2009, reached a record high in 2014 with over 4,000 new policies. This renewed interest in lifetime annuities can be attributed to product design and marketing, which address key behavioural biases, as well as targeted retirement planning education for financial planners in the relevant distribution networks. The most popular annuities are called 'liquid' life annuities where a 15-year guarantee and a one-off option to withdraw the annuity within this period address loss aversion, regret aversion and concerns about access to liquidity. The marketing strategy uses the 'consumption' frame, highlighting spending and income, rather than the traditional 'investment' frame, with the official product description highlighting

9 A recent industry survey indicated that less than one-third of financial advisers were aware of life annuities.

10 At the time of writing the Treasury is undertaking a review of these regulations. 
that the product 'provides regular payments for your lifetime'. ${ }^{11}$ Nevertheless, take-up of lifetime products is very small relative to the retiring cohort. ${ }^{12}$

In other words, the majority of Australian retirees take benefits that leave them uncovered for longevity risk, investment risk and inflation risk. While the public Age Pension does insure against these retirement risks, it is paid at a low rate (around 28 per cent of male average earnings) and, due to the operation of the income and asset means tests, less than 50 per cent of those of eligible age receive the full rate (Department of Social Services 2014). This partial Age Pension coverage, coupled with the preference for non-annuitised products, could raise concerns about retirement income inadequacy in very old age as non-annuitised benefits run out. However, analysis of a panel of Age Pension beneficiaries suggests the opposite, with households in the bottom two wealth quintiles (of full and part Age Pensioners) actually accumulating wealth through retirement (Wu et al. 2015). This suggests that these low-income/low-wealth households are self-insuring against longevity risk and possibly future aged-care costs, and thereby denying themselves a higher standard of living in retirement.

As discussed further below, retirement income stream products are complex and their insurance characteristics are likely to be little understood. It could be the case that Australians are unintentionally exposing themselves to retirement risks because they are unaware of and/or don't understand the characteristics and insurance features of the available products. This lack of awareness and specific product knowledge is likely to be part of a larger problem relating to an increased interaction with complex financial products across the lifecycle.

11 www.challenger.com.au/funds/PDS/GA_Lifetime_PDS.pdf.

12 Less than 7,000 of these liquid lifetime annuities have been sold in the past eight years, yet there are currently 1.1 million retirees aged 60-69. 


\section{The challenge of individual decision-making}

Australia's DC superannuation system mandates participation and a minimum contribution rate, but then leaves individual retirement savers with the responsibility of making often high stakes and complex saving and spending decisions over their lifetime. Typical decisions for individuals include choosing the super fund in which their superannuation savings are managed and accumulate (including the option of setting up their own self-managed fund), superannuation account management (such as switching funds and account consolidation), choosing the investment option or options (from increasingly long menus of single and multi-manager diversified and single options), whether to make or increase voluntary contributions, and if so whether these contributions should be made before or after tax (that is, whether to salary sacrifice or not, if that is an option), and whether to seek and use financial advice, and from whom. Most super fund members also have choice of life and total and permanent disability (TPD) insurance options. Even more choices confront retirees, who have almost unlimited freedom to manage the decumulation phase, which for many will involve questions around eligibility for the means-tested Age Pension, alternative residential options (including the possibility of monetising the house to provide retirement income) and, later in life, eligibility for means-tested support for aged care.

Current policy design and industry practice does provide some support for these decisions through choice architecture (such as the MySuper default), information provision in the form of financial product disclosure, support for financial advice through the regulation of financial advisers and some initiatives to improve financial literacy. However, it is not clear that this support as currently designed really helps people as intended.

\section{Financial literacy and super system and product knowledge}

Every three years since 2002 the ANZ Bank has conducted a national survey of financial literacy, and each subsequent survey has revealed low levels of financial literacy across much of the Australian population (ANZ Bank 2015). These findings are confirmed in 
Australia's contribution to the Financial Literacy around The World (FLaT) study (Agnew et al. 2013a). ${ }^{13}$ The FLaT study was implemented by fielding a survey to a nationally representative sample in each of the contributing countries where financial literacy was measured by answers to three questions (known as the Big Three) that address the basic concepts required to plan for retirement. ${ }^{14}$ The wording of the questions are as follows:

Understanding of interest rate: Suppose you had $\$ 100$ in a savings account and the interest rate was $2 \%$ per year. After 5 years, how much do you think you would have in the account if you left the money to grow? (More than $\$ 102$, Exactly $\$ 102$, Less than $\$ 102$, Do not know, Refuse to answer.)

Understanding of inflation: Imagine that the interest rate on your savings account was $1 \%$ per year and inflation was $2 \%$ per year. After 1 year, how much would you be able to buy with the money in this account? (More than today, Exactly the same, Less than today, Do not know, Refuse to answer.)

Understanding of risk diversification: Buying shares in a single company usually provides a safer return than buying units in a managed share fund. (True, False, Do not know, Refuse to answer.)

The first two questions address economic topics related to saving for retirement, including calculating interest rates and understanding the effect of inflation on purchasing power. Correct responses to these questions also test numeracy. The third question tests understanding of the concept of diversification.

The Australian survey was administered in 2012 to a representative sample of just over 1,000 people over age 18. The responses of the Australian sample are reported in Table 1, and, comparable with other developed countries, find only modest levels of financial literacy (Lusardi and Mitchell 2011b).

13 See Lusardi and Mitchell (2011a, 2011b).

14 The questions were developed by Annamaria Lusardi and Olivia S Mitchell (see Lusardi and Mitchell 2011a). 
Table 1: Proportion of correct answers to the Big Three financial literacy questions

\begin{tabular}{|l|c|c|c|c|}
\hline & \multicolumn{4}{|c|}{$\%$ correct answers } \\
\hline Age & Interest rates & Inflation & Diversification & Total \\
\hline$<35$ & $79 \%$ & $55 \%$ & $42 \%$ & $31 \%$ \\
\hline $36-50$ & $85 \%$ & $69 \%$ & $58 \%$ & $44 \%$ \\
\hline $51-65$ & $80 \%$ & $86 \%$ & $62 \%$ & $52 \%$ \\
\hline
\end{tabular}

Source: Agnew et al. (2013a), Table 2.

While a high proportion of Australians could answer the question about interest rates, the under-35s had trouble with the inflation question, and understanding of diversification was universally poor. It is particularly worrying that less than one-third of younger respondents and only around 50 per cent of 51-65 year olds could answer all three questions. Moreover, in a question asking respondents to selfassess their financial literacy, 86 per cent of the sample considered themselves above average.

Subsequent regression analysis in Agnew et al. (2013a) found an association between financial literacy and retirement planning consistent with international studies reported in Lusardi and Mitchell (2011a), however, other studies suggest that one should be extremely cautious in concluding direct causation between financial education and downstream financial behaviour (Fernandes et al. 2014). In fact, numeracy (tested in the first two of the Big Three questions) has been identified as more important for financial decision-making in a number of experimental studies. In particular, subjects with low numeracy skills have trouble understanding diversification (Bateman et al. 2014), are more likely to be confused by alternative presentations of investment risk (Bateman et al. 2016c), and are insensitive to increasing risk of ruin (Bateman et al. 2016d). Overall, the success of initiatives to improve financial literacy is unclear. Perhaps the 'just in time' alternative, as advocated in Fernandes et al. (2014), should be considered?

At least as important as financial literacy in Australia's DC-world is specific knowledge of the superannuation system to which almost all workers belong. Responses to a subset of superannuation-knowledge questions, included in the 2012 financial literacy survey discussed above, are reported in Table 2 and reveal gaps in key knowledge by a large minority of the sample. 
Table 2: Super system knowledge of a representative sample of super fund members

\begin{tabular}{|l|c|}
\hline & $\begin{array}{c}\text { \% incorrect or } \\
\text { 'do not know' }\end{array}$ \\
\hline What is the mandatory employer contribution rate under the SG? & $34 \%$ \\
\hline $\begin{array}{l}\text { For most people, superannuation is taxed at a higher rate than } \\
\text { a similar investment outside superannuation }\end{array}$ & $38 \%$ \\
\hline $\begin{array}{l}\text { A 'balanced fund' is invested only in safe assets, such as bank } \\
\text { accounts and cash management trusts and term deposits. }\end{array}$ & $60 \%$ \\
\hline $\begin{array}{l}\text { Do you know the minimum age at which you can access your } \\
\text { superannuation account? }\end{array}$ & $48 \%$ \\
\hline If you have any superannuation you will qualify for the Age Pension & $29 \%$ \\
\hline
\end{tabular}

Source: Agnew et al. 2013b.

For example, one would expect all super fund members (irrespective of age) to be aware of the mandatory employer contribution rate, and whether or not superannuation is tax-preferred. However, more than one-third of respondents could not correctly answer either question. More worrying was the large proportion of the sample (close to 60 per cent) who were unaware of the asset allocation of a 'balanced fund' - the typical default option at that time, despite the super savings of around 60 per cent of superannuation members being invested in that option.

In a related study focusing on decumulation decisions, a representative sample of over 800 50-64 year olds, with a super fund but not yet retired, revealed extremely poor understanding of retirement income products. In this survey, respondents were asked to identify which products they were familiar with (from a long list of financial products) and for those nominated were asked to identify key product features relating to period of payment, income guarantee, drawdown flexibility, etc. Responses relating to account-based pensions and life annuities are reported in Table 3.

It is clear from these responses that Australian super fund members approaching retirement have very poor knowledge of the most common retirement benefit product (an account-based pension), and little understanding of an alternative (the lifetime annuity) that provides comprehensive insurance against the retirement risks discussed earlier. More specifically, only one-third of respondents reported that they had heard of a life annuity, and few were aware of its insurance characteristics: only 22 per cent of the sample knew that a life annuity 
paid a 'lifetime' income and only 8 per cent knew that payments are guaranteed. Close perusal of the detailed responses suggested confusion between life annuities and account-based pensions, which may be a further explanation of the trends in take-up of retirement benefits presented earlier.

Table 3: Understanding of retirement benefit products

\begin{tabular}{|l|c|}
\hline Life annuity & Yes \\
\hline Have you heard of this product? & $37 \%$ \\
\hline Does a life annuity offer lifetime income? & $22 \%$ \\
\hline Does a life annuity provide a guaranteed income level? & $8 \%$ \\
\hline Account-based pension & Yes \\
\hline Have you heard of this product? & $48 \%$ \\
\hline $\begin{array}{l}\text { Does an account-based pension offer choice of income subject } \\
\text { to a regulated minimum? }\end{array}$ & $25 \%$ \\
\hline Is withdrawal of capital possible? & $20 \%$ \\
\hline
\end{tabular}

Source: Bateman et al. (2014b).

In a practical sense it is unreasonable to expect all Australian retirement savers (and spenders) to be experts in lifecycle finance and product design. However, the level of understanding and knowledge revealed in these surveys is disappointing and raises questions about the ability of Australian super fund members to make appropriate superannuation and retirement decisions. Policy responses to assist members with these decisions, including information disclosure, choice architecture and financial advice are discussed next.

\section{Information provision through financial product disclosure}

Australia's financial product disclosure initiatives were initially framed in the 1990s on the underlying principle that 'consumers are assumed, for the most part, to be the best judges of their own interests' (Commonwealth of Australia 1997: 191) and that 'disclosure rules would aid and improve the quality of decision making' (Gruen and Wong 2010: 3). Possibly as a response to the 'high-level' regulatory approach and coupled with a focus by product providers on compliance and disclosure obligations, the 'first generation' financial product disclosure statements were long, detailed and complex. 
More recently a series of second-round reforms have included shorter (eight-page) product disclosure statements and the introduction of a regulated default product, known as MySuper, (with its own mandatory disclosure format via a 'product dashboard'). A feature of both new disclosure formats is a 'standard risk measure', endorsed by the superannuation industry and both regulators (ASIC and APRA), where investment risk is required to be presented as 'the expected frequency of negative returns over a 20-year period'.

However, the extent to which this information provision has helped or hindered retirement saving and spending decisions is unclear. Experimental evidence from the US indicates that shorter financial product disclosure statements do not enhance financial decisions (Beshears et al. 2011) and that even well-informed investors may be influenced by non-salient information (Choi et al. 2010).

In the Australian context, Bateman et al. (2016b) investigated whether Australia's newly mandated short-form product disclosure had assisted superannuation fund members to better use and assess the information relevant to super fund investment options. Here the prescribed information includes a description of the option, an expected return objective, suggested time frame, strategic asset allocation, standard risk measure (as discussed above) and risk level. The format for disclosure is prescriptive for all information items except strategic asset allocation where, in practice, super funds present this information in pie charts or tables. A key goal of the regulators, as indicated in the regulatory impact statement (Department of Treasury 2010), was to prescribe risk and return information in a clear format. However, in a lab experiment where student and super fund member subjects were asked to make a series of (incentivised) investment choices using the prescribed information, neither the return nor the risk information were used as expected, with subjects using return information in the opposite direction than expected and generally ignoring the risk information. Surprisingly, the strategic asset allocation information, whether presented as a pie chart or table (and not the main focus of the information disclosure), had the largest marginal impact of all information provided for most of the subjects. This behaviour is consistent with use of the $1 / n$ decision rule, as found in other asset allocation studies including Benartzi and Thaler (2001) for US 401k investment options and Hedesstrom et al. (2007) for investment choice 
in the Swedish Premium Pension Scheme. An overall conclusion is that regulators need to take more care with the testing of product disclosures.

An important motivation for the short-form disclosure was to better communicate expected returns and investment risk for the menu of investment options. Communication of investment risk was specifically investigated in the Australian context in Bateman et al. (2016c), who designed and implemented a discrete choice experiment to investigate the impact of alternative formats for investment risk presentation (including Australia's standard risk measure) on the propensity of individuals to violate some implications of expected utility maximisation when making retirement investment choices. Investment risk was presented in nine alternative formats, including textual and graphical ranges, right and left probability tails and right and left frequency tails (i.e. the standard risk measure). Results identified large differences in rates of violation of rational behaviour by risk presentation format - from around 14 per cent (for range presentations) to 37 per cent (for frequency presentations, which included Australia's standard risk measure). In particular, subjects with low scores on the numeracy and financial literacy scales were less able to 'see through' the alternative risk presentations and for many subjects the effect of the risk presentations was far greater than large changes in the underlying risk levels.

These findings support previous experimental studies that identify the impact of information framing on retirement benefit decisions (including Agnew et al. 2008 and Brown et al. 2008) - and suggest that more care be taken by Australian financial services regulators and industry to address behavioural biases when prescribing formats for mandatory disclosure.

In introducing the short-form disclosure format, the intention of ASIC, the regulator, was to reduce complexity, increase comparability and encourage engagement with financial decisions (Department of Treasury 2010). While there was extensive consultation and even some independent consumer testing of the proposed format, the pre-testing focused on simplicity and comparability but not on how people would use the information provided. 
In other words, the 'information disclosure' approach needs further development to be of help to Australian retirement savers when making their retirement saving and spending decisions. This issue was in fact raised in the final report of the 2014 Financial System Inquiry (FSI 2014), which recommended to 'remove the regulatory impediments to innovative product disclosure and communication with consumers, and to improve the way risk and fees are communicated to consumers' (Recommendation 23).

\section{Choice architecture}

The superannuation system has always made some allowances for members who fail to or just don't want to make decisions. Traditionally, if an employee didn't choose a superannuation fund (if indeed choice was an option), the employer placed contributions in a nominated 'default superannuation fund' and most super fund investment choice menus included a default investment option for members who did not elect one themselves. These arrangements were recently formalised with the introduction of MySuper. Since 2014, new employees who do not choose their super fund have been defaulted into a MySuper product and by 2017 all remaining default fund balances must be transferred into a MySuper product. These products are regulated to have a simple set of product features, irrespective of who provides them, including a single diversified investment option (or a lifecycle strategy where asset allocation is varied with age). Standard fees must be charged to all members, and are generally restricted to administration fees, investment fees, and certain transaction fees on a cost-recovery basis, and standardised reporting on a product dashboard' includes information on the 10-year average return, the return target, the standard risk measure, the level of investment, and fees and other costs.

The jury on MySuper is still out, and, while the initiative provides regulated defaults in the accumulation phase, it does not carry over to decumulation - as was the intent of its architect (Cooper 2010). The absent choice architecture at retirement was another issue raised by in the FSI Final Report, in which it was recommended that the superannuation system 'meet the needs of retirees better by requiring 
superannuation trustees to pre-select a comprehensive income product in retirement for members to receive their benefits, unless members choose to take their benefits in another way' (Recommendation 11).

Overall, it is clear that the current approach to choice architecture is not meeting the needs of Australia's retirement savers and spenders. It is now time for policymakers and industry participants to consider a wider range of choice architecture tools such as use of technology and decision aids, and customised information (Johnson et al. 2012).

\section{Financial advice}

The final arm of support for retirement savers and spenders as they navigate Australia's DC retirement income system is financial advice. Unfortunately, while greater system and product complexity has increased the need for financial advice, questions continue to be raised about conflicts of interest and the quality of advice. A review of the financial planning industry by a Joint Parliamentary Committee (the Ripoll Inquiry) was triggered by several episodes of poor outcomes for clients of some planners (JPCCFS 2009), and there are still regular reports of 'bad behaviour' by advisers. However, the Ripoll Inquiry did lead to the Future of Financial Advice (FoFA) reforms, which aim to improve financial advice by (among other measures) banning conflicted advice, restricting trail commissions, and introducing standards for the conduct of advisers.

Nevertheless, there are still many concerns surrounding financial advice and advisers. Importantly, both public policy and academic studies raise questions about the ability of ordinary people to discern advice quality. A clear example here is an ASIC Shadow Shopping Study of retirement financial advice conducted in 2012, which found that while 86 per cent of clients believed that they had received good advice, only 14 per cent of clients had received good advice under the criteria set by ASIC (ASIC 2012). As well, there are ongoing concerns about the licensing, competence and qualifications of financial advisers. Financial advice was also highlighted in recommendations in the FSI final report, which aim to enhance the quality of advice, including addressing some of the issues surrounding the financial advice industry, such as 'rais[ing] the competency of financial advice providers and introduc[ing] an enhanced register of advisers' 
(Recommendation 25). However, it is clear that there is still a lot to do to ensure that retirement savers and spenders have access to affordable, high-quality and unbiased advice.

In sum, it is not yet clear that we have found the best way to 'help' or 'guide' people through these complex retirement saving and spending decisions.

\section{Concluding comments}

Overall, Australia's retirement income arrangements are well placed to cope with the implications of the ageing population. The multipillar framework for retirement income provision represents world best practice and provides risk diversification, the pre-funded DC Superannuation Guarantee facilitates incentives to work and save, pre-funding enhances intergenerational equity, and the means-tested Age Pension promotes fiscal sustainability.

However, the retirement income arrangements perform poorly in a number of areas. Particularly in need of review are the tax arrangements for superannuation, the lack of policy focus on decumulation, and strategies to 'help' people with increasingly complex financial decisions as they enter and proceed through retirement. A key message is that the retirement income system needs to better support fund members and retirees as they navigate the decision points inevitable in a DC system, which are further complicated under the Australian design through interaction with the Age Pension and aged-care means tests.

It is increasingly evident that super fund members are not equipped to make such decisions, and there is increasing evidence that there are deficiencies in the support framework of financial product disclosure, choice architecture and financial advice. To assist with effective decision-making, future policy will require a combination of broad education and 'just-in-time' knowledge delivery, greater sophistication in choice architecture, improved information provision (through innovative product disclosures and super fund and industry communications) and access to good, unbiased and reasonably priced financial advice. 


\section{References}

Agnew Julie, Anderson Lisa, Gerlach Jeffrey and Szykman Lisa (2008). Who Chooses Annuities? An Experimental Investigation of the Role of Gender, Framing and Defaults. American Economic Review, 98(2): 418-422.

Agnew Julie, Bateman Hazel and Thorp Susan (2013a). Financial Literacy and Retirement Planning in Australia. Numeracy, 6(2): $1-25$.

Agnew Julie, Bateman Hazel and Thorp Susan (2013b). Superannuation Knowledge and Plan Behaviour. JASSA, 1: 45-50.

ANZ Bank (2015). ANZ Survey of Adult Financial Literacy in Australia, May 2015, The Social Research Centre, ANZ, Melbourne.

Australian Bureau of Statistics (ABS) (2009). Employment Arrangements, Retirement and Superannuation, Australia, Cat. No. 6361.0. April to July 2007 (Re-issue). Canberra: Australian Bureau of Statistics.

Australian Council of Social Services (ACOSS) (2014). Poverty in Australia 2014, Australian Council of Social Service, Australia.

Australian Government (2006). A Plan to Simplify and Streamline Superannuation, 9 May, Canberra.

Australian Prudential Regulatory Authority (APRA) (2014). Annual Superannuation Bulletin, June 2013 (Revised 5 February 2014).

Australian Prudential Regulatory Authority (APRA) (2015). Statistics-Quarterly Superannuation Performance, March 2015 (Issued 21 May 2015).

ASIC (2012). Shadow Shopping Study of Retirement Advice, Report 279, Sydney.

Bateman Hazel, Eckert Christine, Geweke John, Louviere Jordan, Satchell Stephen and Thorp Susan (2014). Financial competence, risk presentation and portfolio preferences. Journal of Pension Economics and Finance, 13(1): 27-61. 
Bateman Hazel, Chomik Rafal and Piggott John (2016a). Australia's Retirement Income Policy. In Kate O'Loughlin, Colette Browning, and Hal Kendig (Eds), Ageing in Australia: Challenges and Opportunities. New York: Springer.

Bateman Hazel, Dobrescu Isabella, Newell Ben, Ortmann Andreas and Thorp Susan (2014b). As easy as pie: How retirement savers use prescribed investment disclosures, Journal of Economic Behavious and Organisation, 121: 60-76.

Bateman Hazel, Eckert Christine, Geweke John, Satchell Stephen and Thorp Susan (2016c). Risk presentation and retirement portfolio choice. Review of Finance, forthcoming. rof.oxfordjournals.org/ content/early/2015/03/01/rof.rfv001.full.

Bateman Hazel, Eckert Christine, Iskhakov Fedor, Louviere Jordan, Satchell Stephen and Thorp Susan (2016b). Individual capability and effort in retirement benefit choices, Journal of Risk Insurance, forthcoming.

Bateman Hazel, Kingston Geoffrey and Piggott John (2001). Forced Savings: Mandating Private Retirement Incomes. Cambridge: Cambridge University Press.

Bateman Hazel and Piggott John (1997). Private Pensions in OECD Countries-Australia, Occasional Papers No. 23, Labour Market and Social Policy, OECD, Paris.

Bateman Hazel and Piggott John (2011). Too Much Risk to Insure? The Australian (non-) Market for Annuities. In OS Mitchell, J Piggott and N Takayama (Eds) Securing Lifelong Retirement Income: Global Annuity Markets and Policy. Oxford University Press, pp. 139-176.

Benartzi Shlomo, Previtero Alessandro and Thaler Richard (2012). Annuitisation Puzzles. Journal of Economic Perspectives, 25: 143-164.

Benartzi Shlomo and Thaler Richard (2001). Naive diversification strategies in defined contribution plans. American Economic Review, 91(1): 79-98. 
Beshears John, Choi James, Laibson David and Madrian Brigette (2011). How does simplified disclosure affect individuals' mutual fund choices? In David A Wise (Ed) Explorations in the Economics of Aging. Chicago: University of Chicago Press, pp. 75-96.

Bodie Zvi (1990). Pensions as Retirement Income Insurance. Journal of Economic Literature, 28: 28-49.

Brown Jeffrey (2008). Understanding the role of annuities in retirement planning. In A Lusardi (Ed) Overcoming the Saving Slump. Chicago: University of Chicago Press.

Brown Jeffrey, Kling Jeffrey, Mullainathan Sendhil and Wrobel Marion (2008). Why Don't People Insure Late Life Consumption? A Framing Explanation of the Under-Annuitization Puzzle. American Economic Review, 98(2): 304-309.

Choi James, Laibson David, and Madrian Brigette (2010). Why does the law of one price fail? An experiment on index mutual funds. Review of Financial Studies, 23(4): 1405-1432.

Commonwealth of Australia (1997). Financial System Inquiry Final Report. Canberra: Department of Treasury.

Commonwealth of Australia (2009). Australia's Future Tax System, Report to the Treasurer, December 2009, Part One: Overview. Canberra: Department of Treasury.

Commonwealth of Australia (2015). 2015 Intergenerational Report: Australia in 2055, Canberra: Department of Treasury. www. treasury.gov.au/PublicationsAndMedia/Publications/2015/2015Intergenerational-Report.

Cooper Jeremy (2010). Super System Review, Final Report, Canberra: Commonwealth of Australia.

Department of Social Services (2014). Annual Report 2013-2014, Canberra: Department of Social Services. www.dss.gov.au/sites/ default/files/documents/10_2014/dss_annualreport2013-14.pdf.

Department of Treasury (2010). Regulation Impact Statement (RIS)Financial Services Disclosure Reform, May 2010. ris.finance.gov. au/files/2010/07/FSWG_PDS-RIS_20100713.pdf. 
Department of Treasury (2012). Distributional analysis of superannuation tax concessions, presented to the Superannuation Roundtable, 23 April 2012.

Fernandes Daniel, Lynch John, and Netemeyer Richard (2014). Financial Literacy and Downstream Financial Behaviors. Management Science, 60(8): 1861-1883.

Gallagher Phil (2012). Treasury Measurement of Retirement Income Adequacy, presentation to FEAL Pre-Forum Discussion, 9 February 2012.

Gruen David and Wong Tim (2010). MySuper-Thinking seriously about the default option, presented at the Special Session on Superannuation, Australian Conference of Economists, September 2010, Sydney. archive.treasury.gov.au/documents/ 1922/PDF/03_MySuper.pdf.

Gruen David and Soding Leigh (2011). Compulsory superannuation and national saving, Economic Roundup, Issue 3, 2011. www. treasury.gov.au/PublicationsAndMedia/Publications/2011/ Economic-Roundup-Issue-3/Report/Compulsory-superannuationand-national-saving.

Hedesstrom Ted, Svedsater Henrik and Garley Tommy (2007). Determinants of the use of heuristic choice rules in the Swedish Premium Pension Scheme: An internet-based study. Journal of Economic Psychology, 28(1): 113-126.

Johnson Eric, Shu Suzanne, Dellaert Benedict, Fox Craig, Goldstein Daniel, Haubl Gerald, Larrick Richard, Payne John, Peters Ellen, Schkade David, Wansink Brian and Weber Elke (2012). Beyond Nudges: Tools of Choice Architecture. Marketing Letters, 23: 487-504.

Joint Parliamentary Committee on Corporations and Financial Services (JPCCFS) (2009). Inquiry into financial products and services in Australia, Commonwealth of Australia, November.

Lusardi Annamaria and Mitchell Olivia (2011a). Financial Literacy around the World. Journal of Pension Economics and Finance, 10(4): 497-508. 
Lusardi Annamaria and Mitchell Olivia (2011b). Financial Literacy: Implications for Retirement Security and the Financial Marketplace. Oxford University Press.

Mercer (2014). Melbourne Mercer Global Pension Index. Melbourne: Australian Centre for Financial Studies.

Organisation for Economic Co-operation and Development (OECD) (2013). Pensions at a Glance. Paris: OECD.

Organisation for Economic Co-operation and Development (OECD) (2014a). OECD Factbook 2014-Economic, Environmental and Social Statistics, OECD Publishing. dx.doi.org/10.1787/ factbook.2014-en.

Organisation for Economic Co-operation and Development (OECD) (2014b). OECD Pensions Outlook 2014, OECD Publishing. dx.doi/10.1787/9789264222687-en.

Plan for Life (2015). Detailed annuity statistics, Plan For Life Actuaries and Researchers, Mount Waverley, Victoria, Australia.

World Bank (1994). Averting the Old Age Crisis: Policies to Protect the Old and Promote Growth. Washington, DC: Oxford University Press.

Wu Shang, Asher Anthony, Meyricke Ramona and Thorp Susan (2015). Age pensioner profiles: A longitudinal study of income, assets and decumulation, CEPAR Working Paper 2015/17. Sydney: ARC Centre of Excellence in Population Ageing Research. 
This text is taken from Population Ageing and Australia's Future, edited by Hal Kendig, Peter McDonald and John Piggott, published 2016 by ANU Press, The Australian National University, Canberra, Australia. 